DOI: $10.37190 /$ epe 170212

\title{
PHYTOTOXICITY AND EXTRACTABILITY OF HEAVY METALS FROM INDUSTRIAL WASTES
}

\begin{abstract}
The content, mobility and phytotoxicity of heavy metals in industrial wastes (sewage sludge, carbide residue, flotation tailings) have been determined by chemical characterization and biological test. Assessment of phytotoxicity and content of heavy metals in industrial wastes is important for screening the suitability for their land application or storage. The obtained information may provide a better understanding of environmental risks of heavy metals in wastes. Waste phytotoxicity was arranged in the following order: municipal sewage sludge $>$ industrial sewage sludge $>$ carbide residue $>$ flotation tailings from Żelazny Most $>$ flotation tailings from Gilów. High toxicity of sewage sludge can be caused by a high total content of metals and their forms soluble in $1 \mathrm{M} \mathrm{HCl}$. As a result of waste acidification, zinc, chromium, nickel, and cadmium will be released into the environment from sewage sludge, whereas copper and lead will be released from flotation tailings. The study showed a strongly positive correlation between the content of $\mathrm{Zn}, \mathrm{Ni}, \mathrm{Cr}, \mathrm{Cd}$ in waste and root growth and seed germination inhibition.
\end{abstract}

\section{INTRODUCTION}

Industrial wastes constitute over $90 \%$ of the total waste generated in Poland [1]. Storage of wastes, including industrial ones, is the main way of their disposal in Poland. Numerous studies have proved that industrial waste landfills are harmful to the environment due to water pollution or blowing of heavy metal containing dusts [2-4]. Moreover, the need for waste storage is connected with exclusion from use of large areas which pose a threat connected with penetration of supernatant sludge, but also with the emission of heavy metal containing dusts, which may cause soil pollution and have a negative effect on plant growth in the vicinity of landfills. Therefore, it seems very important to learn the effect of such landfills on living organisms by ecotoxicological assessment using bioindicators representing all trophic levels. Numerous papers indicate that higher

${ }^{1}$ Department of Agricultural and Environmental Chemistry, University of Agriculture in Krakow, al. Mickiewicza 21,31-120 Krakow, e-mail: Agnieszka.Baran@ur.krakow.pl, rrantonk@cyf-kr.edu.pl 
plants may be a key element of a battery of tests which have been hitherto used for this purpose [5-7]. It may be due to the fact that properties of soil, sludge and waste may definitely change bioavailability and toxicity of various pollutants to higher plants.

Currently, wastes which meet appropriate standards are also utilized for reclamation of chemically degraded soils [8]. Once waste material is introduced to soil, even in optimum doses, chemical components pass into the soil solution and to the soil sorption complex [9]. Qualitative and quantitative transformations of soil properties depend on solubility of chemical components after waste application to soil [9].

Industrial wastes are different not only in respect of their total heavy metal content, $\mathrm{pH}$, or total salt content, but also in terms of solubility of individual components depending on the properties of solutions passing through the soil material in contact with the waste [10]. At this point, it should be mentioned that forms of heavy metals (total and soluble) occurring in wastes are very important from the ecological point of view because some are toxic $(\mathrm{Pb}, \mathrm{Cd})$, whereas in excessive amounts, they all are harmful to living organisms. Total metal contents are very often taken into consideration because they are used as indicators of the degree of environmental pollution. However, total contents are not the best indicator of heavy metal bioavailability and mobility.

The aim of this study was to assess the content, mobility and phytotoxicity of heavy metals in industrial wastes (sewage sludge, carbide residue, flotation tailings) by chemical characterization and biological test. Moreover, a possible relationship between the observed toxicity and mobility of heavy metals was studied. Assessment of phytotoxicity and content of heavy metals in industrial wastes is important for screening the suitability for their land application or storage. The obtained information may provide a better understanding of environmental risks of heavy metals in wastes.

\section{MATERIALS AND METHODS}

Characterization of wastes. The analyzed materials were industrial wastes: municipal and industrial sewage sludge (waste code 1908 05; 1908 14), carbide residue (waste code 070180 ) and flotation tailings (waste code 0103 80) [11]. Sewage sludge originated from "Empos" municipal-industrial sewage treatment plant in Oświęcim. Carbide residue was collected from "Osadnik III" landfill owned by Chemical Company Dwory S.A. located in the Oświęcim district in Małopolska region. Carbide residue is a waste formed during carbide production. It is composed mainly of calcium hydroxide but may also contain considerable amounts of pollutants. The basic physicochemical properties of sewage sludge and carbide residue are presented in Table 1. Reaction of the municipal sewage sludge was neutral, while in the case of the industrial sewage sludge it was alkaline. Carbide residue had strongly alkaline reaction. Organic carbon content of the sewage sludge was more than 3-fold higher compared to that of 
carbide residue. Sewage sludge was a significant source of total nitrogen compared to carbide residue [10].

Table 1

Main physicochemical characteristics of the sewage sludge and lime

\begin{tabular}{|l|c|c|c|c|}
\hline \multicolumn{1}{|c|}{ Waste } & $\begin{array}{c}\mathrm{pH} \\
\mathrm{KCl}\end{array}$ & $\begin{array}{c}\mathrm{BEC}^{\mathrm{a}} \\
{\left[\mathrm{mmol}(+) \cdot \mathrm{kg}^{-1}\right]}\end{array}$ & $\begin{array}{c}\mathrm{C}_{\text {org }} \\
{\left[\mathrm{g} \cdot \mathrm{kg}^{-1}\right]}\end{array}$ & $\begin{array}{c}\mathrm{N}_{\text {total }} \\
{\left[\mathrm{g} \cdot \mathrm{kg}^{-1}\right]}\end{array}$ \\
\hline Municipal sewage sludge & 7.2 & 785 & 226.4 & 25.31 \\
\hline Industrial sewage sludge & 7.7 & 851 & 195.7 & 15.26 \\
\hline Carbide residue & 11.3 & 1254 & 62.4 & 0.52 \\
\hline
\end{tabular}

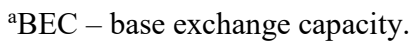

Samples of flotation tailings were collected from two landfills, Gilów and Żelazny Most, belonging to KGHM Polska Miedź S.A. Flotation tailings are obtained as a result of flotation - copper ore enrichment, and constitute the main mass of waste deposited at the Żelazny Most landfill located between the towns of Lubin and Głogów. Formerly, the waste used to be deposited also at the Gilów landfill. Currently, the landfill is closed down and under reclamation [12]. Flotation tailings had alkaline reaction. The sand fractions (80-89\%) were dominant in tailing samples [13].

Chemical and phytotoxicological analysis. 10 averaged samples of each analyzed waste were collected. Carbide residue and flotation tailings were collected at the landfills from the depth of $20 \mathrm{~cm}$ using a soil core sampler. In the laboratory, 10 samples of each waste were mixed on a rotary machine to create a laboratory sample.

Content and solubility of heavy metals. Analysis of waste chemical materials consisted in determination of the total content of heavy metals $(\mathrm{Zn}, \mathrm{Cu}, \mathrm{Ni}, \mathrm{Cr}, \mathrm{Pb}$ and $\mathrm{Cu})$ and their soluble forms. Total heavy metal content in the wastes was determined after digestion in a mixture of $\mathrm{HNO}_{3}$ and $\mathrm{HClO}_{3}(3: 2 \mathrm{v} / \mathrm{v})$. Soluble forms were extracted with $1 \mathrm{M} \mathrm{HCl}$ and distilled water. Extraction of soluble metal forms from the wastes was conducted using static method by single shaking of the wastes to solution ratio of 1:10 for $1 \mathrm{~h}$. The content of metals was determined using an inductively coupled plasma atomic emission spectrophotometer (ICP-AES), model JY 238 ULTRACE, from Jobin Yvon. Each sample of the waste material was analyzed in five replications $(n=25)$. When the results of analyses of those replications differed from one another by more than $\pm 5 \%$, another two analyses of that sample were conducted. A Microsoft Excel 2007 spreadsheet and the Statistica 9.0 package were used for the analysis and presentation of the obtained results.

Assessment of phytotoxicity. Phytotoxkit test. Phytotoxicity of the wastes was assessed using the Phytotoxkit test. As standard in this test three species of plants are used: 
Sorghum saccharatum, Lepidium sativum and Sinapis alba, and two parameters: inhibition of seed germination (IG) and root growth inhibition (IR) are determined [14]. The studied wastes were placed on test plates, moistened with distilled water (to maximum water capacity). The test plates with properly moistened wastes were covered by a paper filter and test seeds were sown at the rate of 10 pieces per plate. The plates prepared in this way were incubated in a horizontal position at $25^{\circ} \mathrm{C}$ in darkness for $72 \mathrm{~h}$. Afterwards, the image was recorded by a digital camera and the root length was measured using Image Tools program for image analyses. The whole experiment was conducted in three replications for each analyzed combination wastes - plant $(n=45: 5$ wastes $\times 3$ plants $\times 3$ replications). The percent inhibition of seed germination (IG) and root growth inhibition (IR) for plant were calculated according to the formula:

$$
I G(I R)=\frac{A-B}{A} \times 100 \%
$$

here $A$ is the mean seed germination or root length in the control and $B$ is the mean seed germination or root length in the tested wastes. A special artificial reference soil was used as the control in the Phytotoxkit test. The control soil is analogous to the artificial soil recommended by Organisation for Economic Co-operation and Development (OECD) for soil toxicity tests and by ISO for toxicity tests with plants. The control soil consisted of sand, kaolin, peat, and was adjusted for $\mathrm{pH}$ with calcium carbonate [14].

\section{RESULTS AND DISCUSSION}

\subsection{PHYTOTOXICITY TESTS}

The assessment of waste phytotoxicity comprised a measurement of inhibition of germination and growth of test plant roots: Sorghum saccharatum, Lepidum sativum and Sinapis alba (Table 2, Figs. 1, 2). The strongest inhibition of germination of the test seeds (from 20 to $100 \%$ ) was observed on the substratum containing municipal sewage sludge, whereas the weakest (from 4 to $6 \%$ ) - on the substratum with flotation tailings collected from the Gilów landfill (Table 2, Fig. 1). On the substratum with carbide residue and both flotation tailings, Sinapis alba was the plant most sensitive to the effect of chemical substances in these wastes. Sorghum saccharatum was less sensitive and Lepidium sativum - the least. On the substratum containing municipal sewage sludge and industrial sewage sludge, the highest inhibition of seed germination was observed for Lepidium sativum, Sinapis alba. Sorghum saccharatum was a less sensitive plant (Fig. 1). The degree of germination inhibition for Sinapis alba seeds was between 6 and $100 \%$, for Lepidium sativum - from 4 to $100 \%$, and for Sorghum saccharatum - only from 5 to $20 \%$ (Fig. 1). 


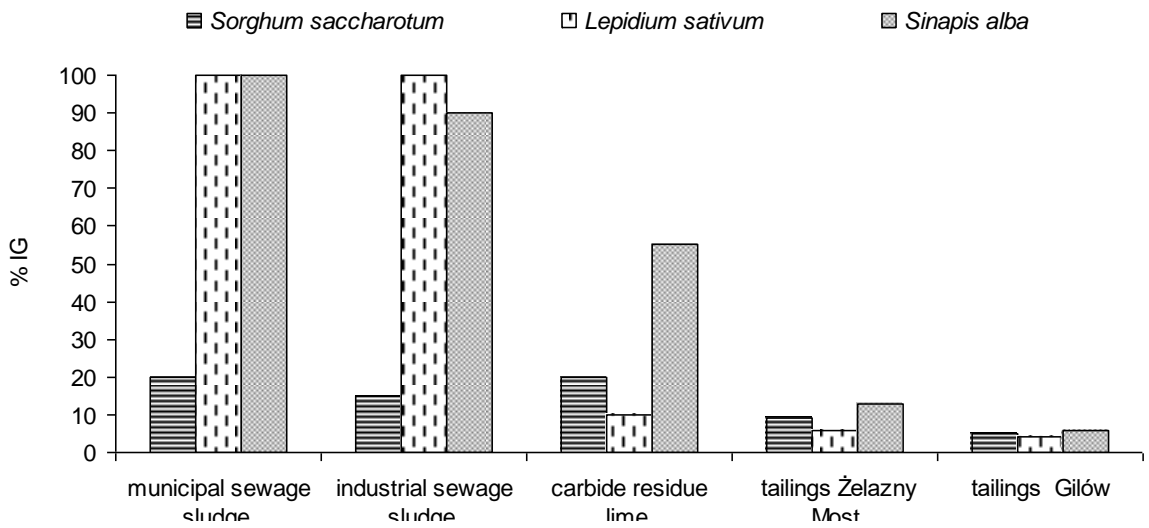

Fig. 1. Waste effect on inhibition of germination

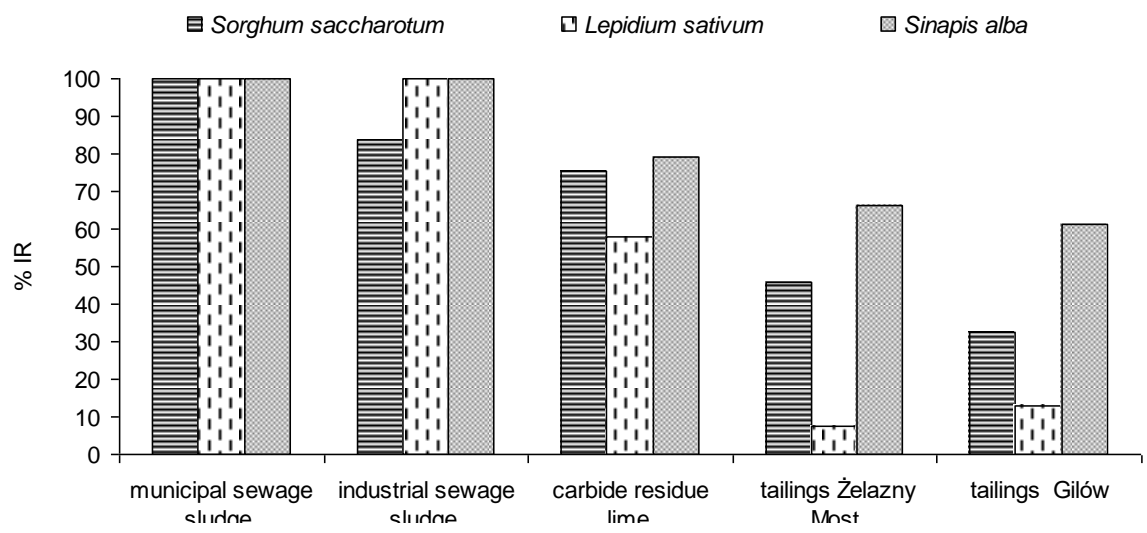

Fig. 2. Waste effect on inhibition of growth of test plant roots

The strongest phytotoxic effect of the wastes (from 83 to $100 \%$ ) on the growth of test plant roots was apparent, similarly to seed germination, in sewage sludge (Table 2, Fig. 2). The weakest inhibitory reaction towards the growth of young test plant roots (from 13 to $61 \%$ ) was observed on the substratum containing flotation tailings collected from the Gilow landfill. Generally, Lepidium sativum proved the most resistant to the phytotoxic effect of the wastes, then Sorghum saccharatum, whereas Sinapis alba was the most sensitive (carbide residue and flotation tailings). On the substratum containing sewage sludge, Sorghum saccharatum was the less sensitive plant (Fig. 2). The degree of the young Lepidium sativum root growth inhibition ranged from 7 to 100\%, Sorghum saccharatum - from 32 to $100 \%$, and Sinapis alba - from 61 to $100 \%$. Summing up the ecotoxicological assessment, we may arrange the analyzed wastes in the following order: municipal sewage sludge $>$ industrial sewage sludge $>$ carbide residue $>$ Żelazny Most flotation tailings $>$ Gilów flotation tailings (Fig. 2). 
Table 2

Plants growth depending on waste

\begin{tabular}{|l|c|c|c|}
\hline \multirow{2}{*}{ Waste } & $\begin{array}{c}\text { Sorghum } \\
\text { saccharatum }\end{array}$ & $\begin{array}{c}\text { Lepidium } \\
\text { sativum }\end{array}$ & $\begin{array}{c}\text { Sinapis } \\
\text { alba }\end{array}$ \\
\cline { 2 - 4 } & \multicolumn{2}{|c|}{ Number of germinated seeds } \\
\hline Control soil & $10 \pm 0$ & $10 \pm 0$ & $10 \pm 0$ \\
\hline Municipal sewage sludge & $8 \pm 0.5$ & 0 & 0 \\
\hline Industrial sewage sludge & $8.5 \pm 1.2$ & 0 & $1 \pm 2.3$ \\
\hline Carbide residue & $8 \pm 0.5$ & $9 \pm 0$ & $6 \pm 1.1$ \\
\hline Tailings ZM & $9 \pm 1.7$ & $9 \pm 0.5$ & $8.7 \pm 0.5$ \\
\hline Tailings G & $9.5 \pm 0.5$ & $9.5 \pm 0.6$ & $9.5 \pm 0.7$ \\
\hline \multicolumn{3}{|c|}{ Woot length [mm] } \\
\hline Control soil & $49.45 \pm 2.1$ & $60.28 \pm 3.4$ & $50.71 \pm 3.8$ \\
\hline Municipal sewage sludge & 0 & 0 & 0 \\
\hline Industrial sewage sludge & $8.00 \pm 2.1$ & 0 & 0 \\
\hline Carbide residue & $12.23 \pm 3.91$ & $25.45 \pm 6.7$ & $10.61 \pm 2.8$ \\
\hline Tailings ZM & $26.78 \pm 7.86$ & $55.84 \pm 13.3$ & $17.06 \pm 5.1$ \\
\hline Tailings G & $33.43 \pm 10.1$ & $52.54 \pm 11.8$ & $19.62 \pm 5.6$ \\
\hline
\end{tabular}

\subsection{CONTENT AND EXTRACTABILITY OF HEAVY METALS}

In terms of chemical properties, the analyzed wastes differed in their total heavy metal content, and solubility of individual components depending on the kind of solution translocating through the waste material. The content of heavy metals in the wastes was connected, in the first instance, with their origin (Table 3). The highest total content of zinc, chromium, cadmium and nickel was found in sewage sludge, while copper and lead content - in flotation tailings. On the other hand, lower total content of zinc, nickel, chromium and cadmium was assessed in flotation tailings collected from the Gilów landfill, whereas the content of copper and lead - in carbide residue. The national waste management plan assumes that in 2018 around $60 \%$ of sewage sludge will be disposed of by thermal processing, and the remaining $40 \%$ by composting, utilisation in agriculture, environment and reclamation. Therefore, there is a necessity for monitoring the heavy metal content in sewage sludge and other wastes intended for soil reclamation $[10,15]$. The mean content of metals in sewage sludge and carbide residue did not exceed the permissible values [16].

The amount of readily water soluble chemical components assessed in the analyzed wastes informs about the effect of the deposited wastes on the surrounding environment. Metals soluble in $1 \mathrm{M} \mathrm{HCl}$ allow one to estimate their mobilization in consequence of acidification of the environment in which they are deposited. On the other hand, water soluble components will be mobilized and will move from the wastes under the influence of precipitation water immediately after their supply into the environment. Solubility of chemical components depends, in the first instance, on their total content in the 
studied material and on $\mathrm{pH}$ [15]. In this study, the highest total and water-soluble content of zinc and nickel was determined in the same municipal sewage sludge and industrial sewage sludge, respectively (Table 3). For copper, lead, chromium and cadmium, this dependence was not confirmed. In consequence of acidification of wastes supplied to soil, the mobilized components will translocate

Content of heavy metals in wastes $\left[\mathrm{mg} \cdot \mathrm{kg}^{-1} \mathrm{~d} . \mathrm{m}.\right]$

\begin{tabular}{|l|c|c|c|c|c|c|}
\hline Industrial waste & $\mathrm{Zn}$ & $\mathrm{Cu}$ & $\mathrm{Ni}$ & $\mathrm{Cr}$ & $\mathrm{Pb}$ & $\mathrm{Cd}$ \\
\hline \multicolumn{7}{|c|}{ Soluble forms in water } \\
\hline $\begin{array}{l}\text { Municipal } \\
\text { sewage sludge }\end{array}$ & $3.55 \pm 0.30$ & $3.92 \pm 0.02$ & $3.16 \pm 0.01$ & $0.21 \pm 0.02$ & $0.30 \pm 0.2$ & $0.05 \pm 0.0$ \\
\hline $\begin{array}{l}\text { Industrial } \\
\text { sewage sludge }\end{array}$ & $2.86 \pm 0.12$ & $4.83 \pm 0.7$ & $4.18 \pm 0.02$ & $0.38 \pm 0.03$ & $0.21 \pm 0.01$ & $0.04 \pm 0.0$ \\
\hline Carbide residue & $0.03 \pm 0.0$ & $0.24 \pm 0.11$ & $0.06 \pm 0.0$ & $0.02 \pm 0.30$ & $0.10 \pm 0.02$ & $0.04 \pm 0.0$ \\
\hline Tailings ZM & $0.04 \pm 0.0$ & nd $^{\mathrm{a}}$ & $0.009 \pm 0.0$ & $0.006 \pm 0.00$ & $0.30 \pm 0.01$ & $0.02 \pm 0.0 \pm 0.00$ \\
\hline Tailings G & $0.38 \pm 0.02$ & $12.45 \pm 2.2$ & $0.04 \pm 0.0$ & $0.07 \pm 0.00$ & $1.88 \pm 0.23$ & $0.04 \pm 0.0$ \\
\hline \multicolumn{7}{|c|}{ Soluble forms in $1 \mathrm{M} \mathrm{HCl}$} \\
\hline $\begin{array}{l}\text { Municipal } \\
\text { sewage sludge }\end{array}$ & $241 \pm 11$ & $210 \pm 8.6$ & $12.40 \pm 0.16$ & $286 \pm 10.4$ & $91.4 \pm 6.10$ & $1.23 \pm 0.01$ \\
\hline $\begin{array}{l}\text { Industrial } \\
\text { sewage sludge }\end{array}$ & $187 \pm 7.8$ & $279 \pm 5.9$ & $13.60 \pm 0.45$ & $192 \pm 15.7$ & $111 \pm 9.67$ & $0.54 \pm 0.0$ \\
\hline Carbide residue & $3.75 \pm 0.09$ & $1.76 \pm 0.2$ & $1.74 \pm 0.12$ & $0.39 \pm 0.01$ & $0.81 \pm 0.06$ & $0.37 \pm 0.0$ \\
\hline Tailings ZM & $33.9 \pm 1.56$ & $949 \pm 10$ & $1.63 \pm 0.04$ & $1.09 \pm 0.04$ & $291 \pm 16.1$ & $0.17 \pm 0.0$ \\
\hline Tailings G & $5.64 \pm 1.10$ & $442 \pm 17$ & $1.35 \pm 0.01$ & $0.88 \pm 0.03$ & $151 \pm 3.8$ & $0.09 \pm 0.0$ \\
\hline \multicolumn{7}{|c|}{ Total content } \\
\hline $\begin{array}{l}\text { Municipal } \\
\text { sewage sludge }\end{array}$ & $991 \pm 34$ & $338 \pm 11.8$ & $28.99 \pm 1.10$ & $305 \pm 3.21$ & $119.4 \pm 14.1$ & $4.94 \pm 0.24$ \\
\hline $\begin{array}{l}\text { Industrial } \\
\text { sewage sludge }\end{array}$ & $914 \pm 29$ & $641 \pm 14.3$ & $43.72 \pm 3.11$ & $276 \pm 11.2$ & $123.4 \pm 0.67$ & $4.71 \pm 0.05$ \\
\hline Carbide residue & $198 \pm 8.5$ & $79.21 \pm 6.9$ & $30.84 \pm 2.02$ & $38.33 \pm 7.9$ & $52.06 \pm 1.70$ & $0.76 \pm 0.0$ \\
\hline Tailings ZM & $262 \pm 10.7$ & $2610 \pm 192$ & $21.19 \pm 0.53$ & $5.28 \pm 0.66$ & $1132 \pm 74$ & $1.00 \pm 0.09$ \\
\hline Tailings G & $42.3 \pm 3$ & $989 \pm 100$ & $3.48 \pm 0.26$ & $2.55 \pm 0.4$ & $169 \pm 21$ & $0.12 \pm 0.0$ \\
\hline \multicolumn{7}{|c|}{ Permitted content of heavy metals } \\
\hline Sewage sludge & 2500 & 1000 & 300 & 500 & 750 & 20 \\
\hline
\end{tabular}

${ }^{\mathrm{a}} \mathrm{nd}$ - not detectable.

${ }^{\mathrm{b}}$ According to [13].

${ }^{\mathrm{c} A c c o r d i n g}$ to $[16]$.

The study has shown that the greatest amounts of zinc, chromium, nickel and cadmium would be mobilized from sewage sludge, whereas copper - from both flotation tailings, and lead - from flotation tailings from the Gilów landfill. The lowest amounts of zinc, copper, chromium and lead will be mobilized in consequence of acidification 
of carbide residue, while nickel and cadmium - from flotation tailings from the Gilów landfill (Table 3).

Table 4

The solubility of metals [\%] relative to their total content in wastes

\begin{tabular}{|c|c|c|c|c|c|c|c|c|c|c|}
\hline \multirow{2}{*}{ Metal } & \multicolumn{4}{|c|}{ Sewage sludge } & \multirow{2}{*}{ Carbide residue } & \multicolumn{4}{c|}{ Tailings $^{\mathrm{b}}$} \\
\cline { 2 - 9 } & \multicolumn{2}{|c|}{ Municipal } & \multicolumn{2}{|c|}{ Industrial } & \multicolumn{2}{c|}{ Żelazny Most } & \multicolumn{2}{c|}{ Gilów } \\
\cline { 2 - 9 } & Water & $1 \mathrm{M} \mathrm{HCl}$ & Water & $1 \mathrm{M} \mathrm{HCl}$ & Water & $1 \mathrm{M} \mathrm{HCl}$ & Water & $1 \mathrm{M} \mathrm{HCl}$ & Water & $1 \mathrm{M} \mathrm{HCl}$ \\
\hline $\mathrm{Zn}$ & 0.4 & 24 & 0.3 & 20 & 0.02 & 3 & 0.02 & 13 & 1.0 & 13 \\
\hline $\mathrm{Cu}$ & 1.2 & 62 & 0.8 & 44 & 0.3 & 2 & nd $^{\mathrm{a}}$ & 36 & 1.3 & 45 \\
\hline $\mathrm{Ni}$ & 11 & 43 & 9.6 & 31 & 0.2 & 6 & 0.04 & 8 & 1.2 & 39 \\
\hline $\mathrm{Cr}$ & 0.1 & 94 & 0.1 & 69 & 0.05 & 1 & 0.1 & 2 & 2.8 & 35 \\
\hline $\mathrm{Pb}$ & 0.3 & 77 & 0.2 & 90 & 0.2 & 2 & 0.03 & 26 & 0.12 & 89 \\
\hline $\mathrm{Cd}$ & 1.1 & 26 & 0.8 & 11 & 5.3 & 49 & 2.0 & 17 & 33 & 75 \\
\hline
\end{tabular}

${ }^{a}$ nd - not detectable.

${ }^{b}$ According to [13].

The degree and mobilization of heavy metals from the studied wastes is evidenced also by the percentage share of soluble elements in relation to their total content (Table 4). Water solubility of investigated metals is small in comparison to their total content, which is connected with low concentration of hydrogen ions in the analyzed wastes. Zinc solubility in distilled water fluctuated from $0.02 \%$ to $1.0 \%$, copper - from 0.3 to $1.3 \%$, nickel - from 0.04 to $11 \%$, chromium - from 0.05 to $2.8 \%$, lead - from 0.03 to $0.3 \%$, and cadmium - from 0.8 to $33 \%$. Solubility of the tested metals in $1 \mathrm{M} \mathrm{HCl}$ was better, fluctuating as follows: zinc 3-24\%, copper $2-62 \%$, nickel $6-43 \%$, chromium $1-94 \%$, lead $2-90 \%$ and cadmium $11-75 \%$ (Table 4 ).

The highest content of zinc and chromium soluble in distilled water was recorded in an extract prepared from flotation tailings from the Gilow landfill, and then exchangeable forms in sewage sludge. The highest share of soluble forms of copper in relation to total content was determined in the extracts from the Gilów tailings, and nickel - from municipal sewage sludge (Table 4). The highest quantities of lead dissolved in distilled water were found in the municipal sewage sludge, whereas the highest share of forms of this element soluble in $1 \mathrm{M} \mathrm{HCl}$, in relation to its total content, was observed in the extract from industrial sewage sludge and flotation tailings from Gilow (Table 4). The highest share of soluble cadmium forms, in relation to its total content, was determined in the extracts from flotation tailings collected from the Gilow landfill. When considering the tested wastes, flotation tailings from Żelazny Most (Table 4) had the lowest share of water-soluble forms of most metals, whereas carbide residue had the lowest amount of forms soluble in $1 \mathrm{M} \mathrm{HCl}$ (except of $\mathrm{Cd}$ ). For cadmium, the lowest share of forms soluble in water and in $1 \mathrm{M} \mathrm{HCl}$ was found in the industrial sewage sludge. 


\subsection{ANALYSIS OF THE CORRELATION COEFFICIENTS}

Analysis of correlation between the content of metals and results of toxicity tests has been presented in Table 5. Positive values of the correlation coefficients indicate a relationship between metal content in wastes and toxicity to organisms, whereas negative values mean that an increase in metal content caused a decrease in sample toxicity. The study showed a strongly positive correlation between the content of $\mathrm{Zn}, \mathrm{Ni}, \mathrm{Cr}$ and $\mathrm{Cd}(1 \mathrm{M} \mathrm{HCl}$, total content $)$ in waste and inhibition of root growth in all the test plants and seed germination (Lepidum sativum and Sinapis alba). The results indicate a negative correlation between the content of $\mathrm{Cu}, \mathrm{Pb}$ in waste and inhibition of root growth and seed germination (Table 5).

Table 5

Correlation analysis for heavy metals content and toxicity results

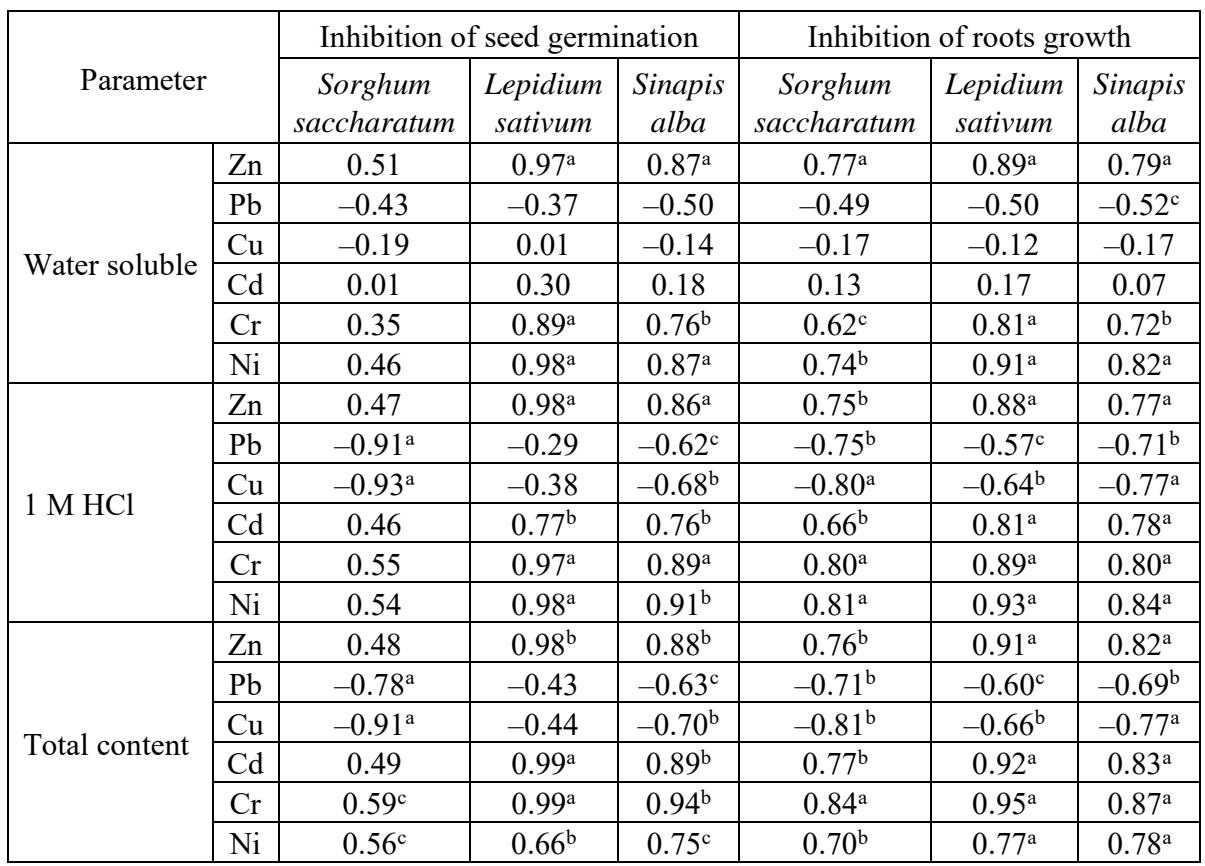

a Significant at $p \leq 0.001$.

bignificant at $p \leq 0.01$.

'Significant at $p \leq 0.05$.

The toxicity of waste was assessed using the Phytotoxkit ${ }^{\mathrm{TM}}$ test. Information was generated on the effect of sewage sludge, carbide residue and flotation tailings on germination and growth of young test plant roots. The studies revealed that Sinapis alba 
was the plant most sensitive to chemical substances in the wastes, therefore it may find application in bioindication of reclaimed landfills. Lepidium sativum proved to be the most resistant to the phytotoxic effect of the carbide residue and flotation tailings. Sorghum saccharatum generally showed sensitivity halfway between Lepidium sativum and Sinapis alba. Sorghum saccharatum was the most resistant to the phytotoxic effect of the sewage sludge. When considering the parameters of toxicity assessment, i.e. seed germination and root growth, it was found that these plants differed considerably in their sensitivity to the effect of chemical substances in the wastes. On the substrates containing carbide residue and flotation tailings, the parameter of the root growth of the test plants revealed a higher sensitivity than the seed germination parameter. In the case of the sewage sludge, the above-mentioned relationship was found only for Sorghum saccharatum. For Lepidium sativum and Sinapis alba, substrates containing both sewage sludges were very toxic. The main symptom of phytotoxicity of the waste was reducing the growth of the roots of the test plants. Roots are the first part of plant exposed to toxic substances in waste, thus in them the primary reactions to the toxic effect of various substances can be observed $[17,18]$. Heavy metals inhibit root growth, which is associated with a decrease in mitotic activity of cells [19]. The dependence has been confirmed by other authors, who reported that germination capacity is an indicator affected to a relatively small extent by the presence of heavy metals, oil derivatives, some polymers, composts, sludge, bottom sediment or municipal landfill leachates [20-24]. It was demonstrated that many plants germinate in a polluted environment, but later stop growing, therefore the root growth parameter is more sensitive and useful for phytoxicity tests $[5,21]$. Sewage sludge proved to be the most toxic waste. It revealed the highest content of total zinc, chromium, nickel and cadmium and their soluble forms.

The high phytotoxicity of sewage sludge can also be caused by the salinity of the waste. Numerous studies have shown that salinity of sewage sludge or composts produced from them can cause a phytotoxic effect, or even a genotoxic one [24]. Sludge toxicity can be influenced also by the basic properties of sludge - organic load parameters (BOD, COD) and total suspended solids [24]. Compared to sewage sludge, the content of heavy metals in carbide residue was not very high, despite the fact that this substratum considerably limited the growth of test plants. It may be connected with strongly alkaline reaction of this waste. Under these conditions, inhibition of water absorption by plants from soil or substratum is observed and thereby inhibition of plant growth (physiological drought). In general, plants are very sensitive to strongly alkaline reaction. Most plants prefer slightly acidic or neutral reaction of soil. Flotation tailings collected from the Gilow landfill were the least toxic to the studied plants. At this point, it should be mentioned that the landfill is currently being reclaimed, so the waste showed more favorable growth conditions for plants. The Gilów landfill is subject to reclamation in the direction of water and forestry sectors. Currently, the unused landfill is covered with forest and autogenic plants [15]. The relatively low toxicity of flotation tailings to plants was caused by slightly alkaline reaction of the tested waste. Numerous 
authors observed that waste reaction may affect heavy metal mobility in the environment $[8,10]$. Metals may pass into less readily soluble forms at higher $\mathrm{pH}$. Slightly alkaline reaction of flotation tailings may decrease solubility of heavy metals [12].

To summarize, wastes supplied to the environment have a direct effect on soil and surrounding areas. Therefore, after the first precipitations, readily water-soluble chemical components become mobilized and easily penetrate into soils. In the presented investigations, particularly copper concentration in the water extract prepared from flotation tailings from Gilów, as well as zinc, copper and nickel content in sewage sludge raise concern. Physical, chemical and biological processes occurring in sewage sludge and post-flotation sludge and in carbide residue deposited or added to the soil may lead to mobilization of higher amounts of chemical elements which penetrate into the soil $[10,15]$. Hydrogen ions become concentrated in the washed wastes and therefore $\mathrm{pH}$ value decreases. Waste acidification favors mobilization of metals, as shown in the presented investigations. In consequence of waste acidification, the content of metal forms soluble in $1 \mathrm{M} \mathrm{HCl}$ increased in relation to water-soluble forms, depending on the tested waste, 15-845 times for $\mathrm{Zn}$, from 7 to 58 times for $\mathrm{Cu}, 3-181$ times for $\mathrm{Ni}$, from 13 to 1362 times for $\mathrm{Cr}$, from 8 to 528 times for $\mathrm{Pb}$, and from 12 to 14 times for $\mathrm{Cd}$.

\section{CONCLUSIONS}

- Sinapis alba was the plant most sensitive to chemical substances in wastes, therefore it may be applied for bioindication of reclaimed landfill sites.

- Sewage sludge limited germination and growth of test plant roots to the greatest extent. Waste phytotoxicity formed the following order: municipal sewage sludge $>$ industrial sewage sludge $>$ carbide residue $>$ flotation tailings from Żelazny Most $>$ flotation tailings from Gilów.

- High toxicity of sewage sludge can be caused by a high total content of metals and their forms soluble in $1 \mathrm{M} \mathrm{HCl}$. In consequence of waste acidification, zinc, chromium, nickel and cadmium will be released into the environment from sewage sludge, whereas copper and lead from flotation tailings.

\section{ACKNOWLEDGEMENTS}

The research was financed by the Ministry of Science and Higher Education of the Republic of Poland.

\section{REFERENCES}

[1] PrZeniosŁo S., TYMiŃSKi M., MAlon A., Analysis of quantitative changes in post-mining and postprocessing wastes, as well as salines and saltwaters in Poland, Polish Geol. Rev., 2006, 54 (8), 668 (in Polish). 
[2] Boularbah A., Schwartz C., Bitton G., Boularbah J.L.M., Heavy metals contamination from mining sites in South Morocco. 1. Use of a biotest to assess metal toxicity of tailings and soils, Chemosphere, 2005, 63, 802.

[3] Esakku S., Palanivelu K., Kurian J., Assessment of heavy metals in a municipal solid waste dumpsite, Sust. Landfill Manage., 2003, 139.

[4] Śliwka E., KoŁwzan B., Grabas K., Klein J., Korzeń R., Chemical composition and biological properties of weathered drilling wastes, Environ. Prot. Eng., 2012, 38 (1), 129.

[5] AN Y.J., Soil ecotoxicity assessment using cadmium sensitive plants, Environ. Pollut., 2004, 127, 21.

[6] Krik J.L., Klironomos J.N., Lee H., Trevors J.T., Phytotoxicity assay to assess plant species for phytoremediation of petroleum-contaminated soil, Bioremed. J., 2002, 6 (1), 57.

[7] Romanowska-Duda Z.B., Grzesik M., Hazem M., Kalaji H., Phytotoxkit test in growth assessment of corn as an energy plant fertilized with sewage sludge, Environ. Prot. Eng., 2010, 36 (1), 73.

[8] Jasiewicz C., ANTONKIEWicz J., Baran A., Assessment of the use of municipal and industrial wastes in agriculture, Pol. J. Chem. Techn., 2007, 9 (3), 15.

[9] JASIEWICZ C., BARAN A., The effect of organic wastes on changes of selected indicator of soil fertility, Ecol. Chem. and Eng., 2008, 15 (10), 1086.

[10] ANTONKIEWICZ J., Assessment of bioavailability of heavy metals in wastes used for biological reclamation of hazardous waste landfill, Scientific Papers of the University of Agriculture in Krakow, 2011, 481 (358), 358, 119.

[11] Regulation of the Minister of the Natural Environment on catalog of wastes dated 9 December 2014. Journal of Laws of Poland, Item 1923.

[12] Śliwka M., Baran A., WieczoreK J., Evaluation of toxic metal bioaccumulation in a reservoir of flotation tailings, J. Environ. Studies, 2013, 22 (3), 909.

[13] Baran A., ŚliwKa M., Lis M., Selected properties of flotation tailings wastes deposited in the Gilów and Żelazny Most wastes reservoirs regarding their potential environmental management, Arch. Min. Sci., 2013, 58 (3), 96.

[14] Phytotoxkit. Seed germination and early growth microbiotest with higher plants. Standard Operational Procedure, Nazareth, Belgium, MicroBioTest, Inc., 2004, 24.

[15] AnTONKIEwICZ J., Effect of fly ashes and sewage sludge on Fe, Mn, Al, Si and Co uptake by grass mixture, J. Ecol. Eng., 15 (3), 2014, 6.

[16] Regulation of the Minister of the Natural Environment on municipal sewage sludge dated 6 February 2015. Journal of Laws of Poland, Item 257.

[17] JONIEC J., FURCZAK J., Multi-annual studies on phytotoxicity of podzolic soil amended with municipale industrial sawage sludge using of Lepidium sativum as bioindicator, Adv. Agricult. Sci. Problem Iss., 2009, 535, 173.

[18] Radić S., Prolić M., Pawalica M., PevaleK-Kozlina B., Cytogenetic effects on osmotic stress on the root meristem cells Centaurea ragusina L., Environ. Exp. Bot., 2005, 54, 213.

[19] FusCONI A., Effects of cadmium on meristem activity and nucleus ploidy in roots of Pisum sativum L. cv. Frisson seedlings, Environ. Exp. Bot., 2006, 58 (1-3), 253.

[20] Baran A., JASIEWICZ Cz., KLIMEK A., The toxicity content of zinc and cadmium in soil to different plant species, Proc. ECOpole, 2008, 2 (2), 417.

[21] OleszCZuK P., The toxicity of compost from sewage sludges evaluated by direct contact tests Phytotoxkit and Ostarcodotoxkit, Waste Manage., 2008, 28, 1645.

[22] Kopeć M., GONDEK K., BARAN A., Assessment of respiration activity and ecotoxicity of composts containing biopolymers, Ecotoxicol. Environ. Saf., 2013, 89, 137.

[23] Steliga T., The use of biotests in estimation of weathered drilling waste bioremediation, Arch. Environ. Prot., 2011, 37 (2), 61. 
[24] RaClavSKÀ H., DoŝKÀŘOVÀ Š., ŠKROBÀnKovÀ H., Ecotoxicity of sewage sludges from waste water treatment plant, J. Polish Min. Eng. Soc., 2011, 1 (27), 39.

[25] Antonkiewicz J., PARA A., The use of dialdehyde starch derivatives in the phytoremediation of soils contaminated with heavy metals, Int. J. Phytorem., 2016, 18, 3, 245. 